\title{
Radiabeam Industrial Accelerator Commissioning
}

Cooperative Research and Development Agreement Final Report

CRADA Number: FRA-2016-0047

\section{Fermilab Technical Contact: Charlie Cooper}

Summary Report

30 September 2019 


\section{NOTICE}

This report was prepared as an account of work sponsored by an agency of the United States government. Neither the United States government nor any agency thereof, nor any of their employees, makes any warranty, express or implied, or assumes any legal liability or responsibility for the accuracy, completeness, or usefulness of any information, apparatus, product, or process disclosed, or represents that its use would not infringe privately owned rights. Reference herein to any specific commercial product, process, or service by trade name, trademark, manufacturer, or otherwise does not necessarily constitute or imply its endorsement, recommendation, or favoring by the United States government or any agency thereof. The views and opinions of authors expressed herein do not necessarily state or reflect those of the United States government or any agency thereof.

Available electronically at http://www.osti.gov/bridge

Available for a processing fee to U.S. Department of Energy and its contractors, in paper, from:

U.S. Department of Energy Office of Scientific and Technical Information

P.O. Box 62

Oak Ridge, TN 37831-0062

phone: 865.576 .8401

fax: 865.576 .5728

email: mailto:reports@adonis.osti.gov

Available for sale to the public, in paper, from:

U.S. Department of Commerce

National Technical Information Service

5285 Port Royal Road

Springfield, VA 22161

phone: 800.553 .6847

fax: 703.605.6900

email: orders@ntis.fedworld.gov

online ordering: http://www.ntis.gov/ordering.htm 
In accordance with Requirements set forth in Article $X$ of the CRADA document, this document is the final CRADA report, including a list of Subject Inventions, to be forwarded to the Office of Science and Technical Information as part of the commitment to the public to demonstrate results of federally funded research.

CRADA number: $\quad$ FRA-2016-0047

CRADA Title: $\quad$ Radiabeam Industrial Accelerator Commissioning

Parties to the Agreement: RadiaBeam, LLC and Fermi Research Alliance, LLC

\section{Abstract of CRADA work:}

Radiabeam is building an industrial accelerator funded by the Defense Nuclear Detection Office in the Department of Homeland Security. The accelerator is designed as a radiation source for systems intended to find Special Nuclear Materials or contraband in cargo containers. Fermilab staff will travel to Radiabeam to help in commissioning of the accelerator. This work would primarily be focused on optimization of beam dynamics. In doing this, Fermilab would gain valuable general information about industrial linac operation and commissioning. Fermilab will also gain specific information about this new accelerator in support of a planned larger collaboration with Radiabeam.

\section{Summary of Research Results:}

The laboratory supported the travel and time for two engineers from Fermilab's Technical Division with expertise in radio-frequency systems and accelerators to assist in Radiabeam's commissioning of their new accelerator. This accelerator detailed in the below referenced paper had some new design features specific for rail cargo inspection. Because of these new features, Radiabeam requested Fermilab's expertise in commissioning of the system. While Fermilab staff did not participate directly in the commissioning, they instead advised Radiabeam on commissioning procedures and the results which were appropriate for their accelerator. The accelerator was commissioned successfully without any unforeseen issues.

\section{Related Reports, Publications, and Presentations:}

Kutsaev, Sergey V.; Agustsson, Ronald; Arodzero, Anatoli; Boucher, Salime; Faillace, Luigi; Hartzell, Josiah; Ziskin, Vitaliy. "Electron Linac with Deep Energy Control for Adaptive Rail Cargo Inspection System." 2015.

\section{Subject Inventions listing:}

None 
4 Final Report for CRADA FRA-2016-0047

Report Date: 30 September 2019

Technical Contact at Fermilab: Charlie Cooper

This document contains NO confidential, protectable or proprietary information. 